\title{
THE EFFECT OF VIDEO AND SIMULATION COUNSELLING ON CHILDREN'S KNOWLEDGE ABOUT HAND WASHING USING SOAP IN THE PRIVATE VOCATIONAL SCHOOL OF LAMBANDIA DISTRICT EAST KOLAKA DISTRICT
}

\author{
Nur Ahmad ${ }^{1}$, Tasnim Tasnim², Herianto Wahab ${ }^{3}$ \\ ${ }^{1,2,3}$ Magister of Public Health Study Program, College of Health Sciences Mandala Waluya \\ Kendari, Southeast Sulawesi, Indonesia
}

Corresponding Author: Nur Ahmad

Email : nurahmadners@yahoo.co.id

\section{Abstract}

Background: Washing hands with soap is wrong for school children due to the child's lack of knowledge which is caused by a lack of exposure to information from schools, especially learning materials about proper and correct hand washing. School-age children are an age that is prone to various diseases, such as diarrhoea and worms. in 2018 the number of cases of diarrhoea in East Kolaka was 593. The largest cases of diarrhoea in East Kolaka District were in Lambandia District, with 187 cases of diarrhoea, the majority of which occurred in schoolage children. To find out the effect of video and simulation counselling on children's knowledge about washing hands with soap at the Lambandia District Elementary School, East Kolaka.

Methods: This study uses a quantitative research design with a quasi-experimental research design. This research was conducted in three SDN Lambandia District. The study population was school children with a sample of 70 children who were divided into two experimental groups and one control group. Sampling was done by a proportionate random sampling method. Result: The findings show from statistical tests that there is an effect of video and simulation on children's knowledge. This can be seen from $p$-value both of them are $0.000<\alpha=0.05$.

Conclusion: There was an effect of video screening and simulation on children's knowledge about washing hands with soap at the Lambandia District Elementary School, East Kolaka Regency

Key words: counselling, video, simulation, hand washing 


\section{INTRODUCTION}

Washing Hands with Soap (CTPS) is the act of cleaning hands using soap under running water which aims to keep the hands clean(1). Washing hands with soap is an effort to prevent disease(2). Hands are the main medium for transmitting diseasecausing germs(3). Hands are often the agents that carry germs and cause pathogens to pass from one person to another either by direct contact or indirect contact(4). Increasing the degree of public health must be supported by human health resources(5). One of the efforts to improve behaviour to do that is through health education(6).

Most elementary school children already know how to wash their hands but still have diarrhoea (7). This is influenced by bad attitudes and actions(8). Respondents who already have good knowledge about how to wash their hands have not applied it in their daily lives(9).

Providing health promotion using the media can provide a difference in action between before and after treatment (10). School-age children are an age that is prone to various diseases, such as diarrhoea and worms(11). Washing hands using soap under running water is more effective at removing dirt and dust on the surface of the skin, is an effort to reduce the number of diseasecausing microorganisms such as viruses, bacteria, and parasites that stick to the hands (12).

Based on the results of the Basic Health Research in 2013, the prevalence period of diarrhoea in Southeast Sulawesi was $7.3 \%$, with the incidence of diarrhoea among children under five around $5 \%$. The number of cases of diarrhoea handled in 2016 was 35,864 cases or $46.77 \%$ of the estimated cases, a decrease compared to 2015 as many as 41,071 cases or $77.74 \%$ of the estimated cases. Meanwhile, the data on the incidence of diarrhoea in the East Kolaka Regency were 593 cases in 2018(13).

Based on a preliminary study in 2018, the number of cases of diarrhoea in East Kolaka was 593. The largest cases of diarrhoea in East Kolaka District were in Lambandia District, with 187 cases of diarrhea, the majority of which occurred in school-age children. (14). The results of an interview with a teacher at an elementary school in Lambandia District showed that the habit of washing hands in children was still low, this was due to the absence of special facilities for washing hands and the absence of complete information regarding how and when to wash hands properly and correctly. Based on these reasons, the researchers are interested in researching with the title of the effect of video counselling and simulations on children's knowledge about washing hands with soap at Elementary Schools, Lambandia District, East Kolaka Regency.

\section{METHOD}

The design of this research is a quasiexperiment (15). The implementation time is from July to August 2020 in three SDN Lambandia District. The study population was school children with a sample of 70 children who were divided into two experimental groups and one control group. The questionnaire was used as a data collection method (16).

\section{RESULT}

Table 1.It shows that most of the respondents (58\%) are 10 years old, as much as $(34 \%)$ of the respondents are 11 years old and $(8 \%)$ of the respondents are 9 years old.

Table 2.It shows that before the intervention (pre-test), respondents in the video group were mostly knowledgeable enough $(78.1 \%)$ and respondents in the simulation group had more knowledge (66.7\%). After the intervention (post-test) there was a change, most respondents in the video group had good knowledge $(53.1 \%)$ and the respondents in the simulation group had more good knowledge (83.3). Respondents in the control group at the time of the pre-test were more knowledgeable $(62.1 \%)$ and at the time of the post-test there were no changes, namely (62.1\%) of respondents who had sufficient knowledge. 
Table 3.Based on the results of statistical tests using the Wilcoxon test, it was obtained a $\mathrm{p}$-value of $0,000<\alpha=0.05$, meaning that there was an effect of counselling with the video method on the actions of elementary school children about washing hands with soap in the Lambandia District, East Kolaka Regency.
Table 4.Based on the results of statistical tests using the Wilcoxon test, the p-value was obtained of $0.000<\alpha=0.05$, meaning that there was an effect of counselling with a simulation method on the knowledge of elementary school children about washing hands with soap in the Lambandia District, East Kolaka Regency.

Table 1

Characteristics of Respondents based on Age in Each Group

\begin{tabular}{c|c|c}
\hline Age & $\mathbf{n}$ & \% \\
\hline 9 & 6 & 8 \\
10 & 46 & 58 \\
11 & 27 & 34 \\
\hline Total & $\mathbf{7 9}$ & $\mathbf{1 0 0}$ \\
\hline
\end{tabular}

Table 2

Descriptive Knowledge Change in the Intervention and ControlGroups

\begin{tabular}{|c|c|c|c|c|c|c|c|c|c|c|c|c|}
\hline \multirow{4}{*}{$\begin{array}{c}\text { Knowle } \\
\text { dge }\end{array}$} & \multicolumn{12}{|c|}{ Changes in the Intervention and Control Group } \\
\hline & \multicolumn{4}{|c|}{ Video Group } & \multicolumn{4}{|c|}{ Simulation Group } & \multicolumn{4}{|c|}{ Control Group } \\
\hline & \multicolumn{2}{|c|}{ Pre-test } & \multicolumn{2}{|c|}{ Post-test } & \multicolumn{2}{|c|}{ Pre-test } & \multicolumn{2}{|c|}{ Post-test } & \multicolumn{2}{|c|}{ Pre-test } & \multicolumn{2}{|c|}{ Post-test } \\
\hline & $\mathbf{N}$ & $\%$ & $\mathbf{n}$ & $\%$ & $\mathbf{N}$ & $\%$ & $\mathbf{n}$ & $\%$ & $\mathbf{n}$ & $\%$ & $\mathbf{n}$ & $\%$ \\
\hline Well & 0 & 0 & 1 & 53 & 0 & 0 & 15 & 83.3 & 1 & 3.4 & 3 & 10.3 \\
\hline Eno & 25 & 7.1 & 15 & 46.9 & 12 & 66.7 & 3 & 16.7 & 18 & 62.1 & 18 & 62.1 \\
\hline Less & 7 & 21.9 & 0 & 0 & 6 & 33.3 & 0 & 0 & 10 & 34.5 & 8 & 27.6 \\
\hline Total & 32 & 100 & 32 & 100 & 18 & 100 & 18 & 100 & 29 & 100 & 29 & 100 \\
\hline
\end{tabular}

Table 3

The Effect of Video Screening About Hand washing with Soap on the Knowledge Level of Elementary School Children

\begin{tabular}{cccc}
\hline \multirow{2}{*}{ Knowledge } & \multicolumn{2}{c}{ Measurement Time } & \multirow{2}{*}{ Statistic test } \\
\cline { 2 - 3 } & Before & After & \\
Well & 0 & 17 & \\
Enough & 25 & 15 & P-Value $=$ \\
Less & 7 & 0 & 0.000 \\
\hline total & 32 & 32 & \\
\hline
\end{tabular}

Table 4 


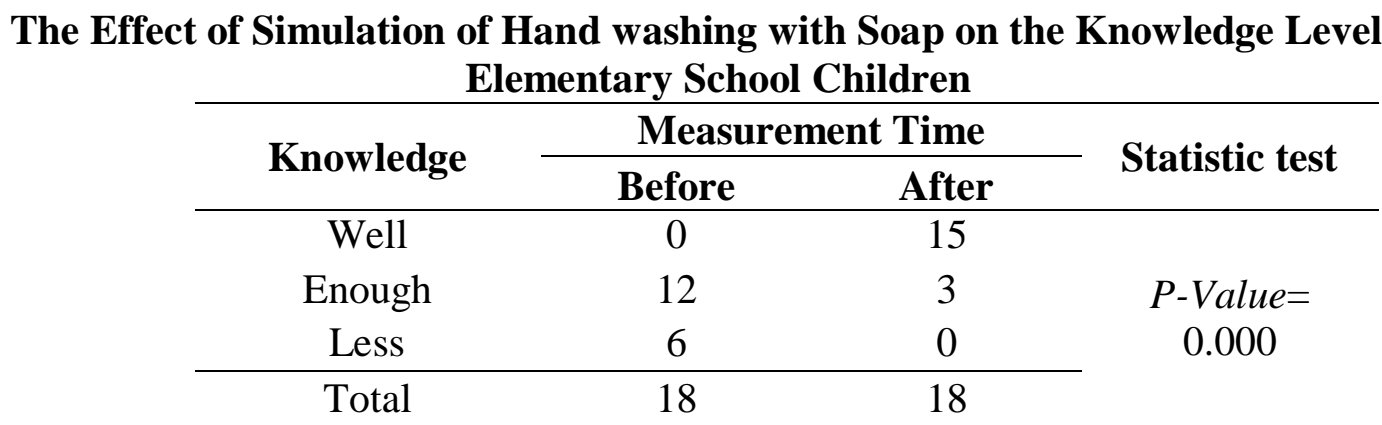

\section{DISCUSSION}

The effect of video screenings about washing hands with soap on the knowledge of elementary school children in Lambandia district

The results showed that there were 25 respondents with sufficient knowledge but after being given treatment in the form of video playback, 15 respondents still had sufficient knowledge and 10 respondents increased their knowledge to be good. Respondents with unknown knowledge amounted to 7 respondents and after being given treatment, all respondents increased their knowledge to be good. While respondents with good knowledge before being given treatment did not exist after being given the treatment, their knowledge increased to 17 respondents. This means that the video playback method can increase the knowledge of elementary school children in the Lambandia district.

At the final measurement, all respondents experienced an increase in their knowledge score compared to the initial measurement (pre-test). This shows that there is a difference in knowledge at the beginning of the measurement compared to the final measurement (post-test). In line with research (17) regarding the effect of video viewing interventions on knowledge, attitudes, and actions about washing hands with soap for students of SDN 10 Kobawo. Show that The difference in students' knowledge about washing hands with soap obtained the results of the McNemar p-value was 0.002 , so statistically, there was a difference in knowledge about washing hands with soap before and after the intervention of video viewing was carried out on students.

The results showed that there was an effect of counselling with the video method on the knowledge of elementary school children about washing hands with soap in the Lambandia District, East Kolaka Regency. These results are in line with the research(18) about the effect of hand washing with video media on hand washing practices. Show that there is an effect of counselling about washing hands with video media on the practice of washing hands among students of SDN Nogotirto. Extension with video media is a medium following the characteristics of elementary school children who are very interested in new things. Children are given counseling using these media to maintain children's health through washing hands. So that, respondents can receive information through the ear in hearing and the eye insight so that the information presented can be received well.

Extension using video media about washing hands with soap for elementary school children in the District of Lambandia, East Kolaka Regency, generally increases children's knowledge to be better, although at first many still imagine about washing hands with soap before counselling. However, after being given the intervention, the child became more understanding and easier to understand what was explained because the video was accompanied by moving pictures and sounds, attracting children's attention so that the material received was stored in their memory longer. Meanwhile, children who still have sufficient knowledge about hand 
washing are caused because they do not pay attention to and understand the health messages conveyed via video during the intervention process. The effect of giving simulations about washing hands with soap on the knowledge of elementary school children in Lambandia district.

The results showed that there were 12 respondents with sufficient knowledge, but after being given treatment in the form of simulation, 3 respondents still had sufficient knowledge and 9 respondents increased their knowledge to be good. Respondents with less known knowledge amounted to 6 respondents and after being given treatment, all respondents increased their knowledge to be good. While respondents with good knowledge before being given treatment did not exist after being given the treatment, their knowledge increased to 17 respondents. This means that the simulation method can increase the knowledge of elementary school children in the Lambandia district.

At the final measurement, all respondents experienced an increase in their knowledge score compared to the initial measurement (pre-test). This shows that there is a difference in knowledge at the beginning of the measurement compared to the final measurement (post-test). In line with (19) regarding the effect of health promotion interventions on knowledge, attitudes, and behaviour of hand washing in fifth-grade students of Inpres Borong Jambu I Elementary School, Makassar City. State that the pre-test results on knowledge showed that the average respondent increased to be good knowledge after being given health promotion interventions. And the results of research and statistical tests show that the knowledge variable has a significant difference in the knowledge variable about washing hands of students between before and after the health promotion intervention is carried out.

The results showed that there was an effect of counselling with a simulation method on the knowledge of elementary school children about washing hands with soap in the Lambandia District, East Kolaka Regency. These results are in line with the research(20) regarding the effect of health promotion interventions on knowledge, attitudes, and practices of washing hands with soap in grade 5 at SDN Pengasinan IV, Bekasi City. Show that it is proven that the health promotion interventions that have been given in the research can affect changes for the better. This study shows that knowledge is significant between the initial measurement and the final measurement.

Counselling by providing simulations about washing hands with soap to elementary school children in the Lambandia District, East Kolaka Regency, generally increases children's knowledge for the better. Through the provision of simulations in the learning process, their knowledge increases, which previously did not become known. A school is a place for the formation of children's knowledge in addition to the family environment. This can provide children's knowledge to learn to apply washing hands with soap in everyday life. Meanwhile, children who still have sufficient knowledge about hand washing are due to their lack of attention and understanding of the messages conveyed during the simulation.

\section{CONCLUSION}

There was an effect of video screening and simulation on children's knowledge about washing hands with soap at the Lambandia District Elementary School, East Kolaka Regency. This study suggested the school should provide adequate facilities to apply proper and proper hand washing to children. The hand washing must be provided a bar of soap and the participation of the teacher in setting an example in getting children to wash their hands. Activating School Health Enterprises in an integrated cross-programmatic and cross institutions should give the effort to improve the ability to live healthily and establish PHBS for students, school members, and the community. 


\section{REFERENCES}

1. Devis Y, Fahruzi Z. Lectures and group discussion methods effective increased the students knowledge about hand washing using soap. Jurnal Kesehatan Komunitas/Journal of Community Health. 2017;3(4):159-63.

2. Sitorus N, Fransisca L. Pengaruh Pendidikan Kesehatan Terhadap Pengetahuan dan Sikap Cuci Tangan pakai Sabun pada Siswa SD Negeri 157 Kota Palembang Tahun 2014. JPP (Jurnal Kesehatan Poltekkes Palembang). 2014;2(14).

3. Khoiruddin K, Kirnantoro K, Sutanta S. Tingkat Pengetahuan Berhubungan dengan Sikap Cuci Tangan Bersih Pakai Sabun Sebelum dan Setelah Makan pada Siswa SDN Ngebel Tamantirta, Kasihan, Bantul, Yogyakarta. Jurnal Ners dan Kebidanan Indonesia. 2015;3(3):17680.

4. Kemenkes R. Pusat data dan informasi kementerian kesehatan RI. Jakarta: infodatin. 2014.

5. Akbar MI. Analusis of the needs of general praktitioners in Public Health Centres using Health Workload Method. Public Health of Indonesia. 2020;6(2):63-9.

6. Saraswati PS, Tasnim T, Sunarsih S. Pengaruh Media Whatsapp Dan Leaflet Terhadap Perilaku Pemeriksaan Payudara Sendiri Pada Siswi Sekolah Menengah Atas Di Kota Kendari. Alsihah: The Public Health Science Journal. 2019;11(2).

7. Igiany PD, Sudargo T, Widyatama R. Efektivitas penggunaan video dan buku bergambar dalam meningkatkan pengetahuan, sikap, dan keterampilan ibu mencuci tangan memakai sabun. Berita Kedokteran Masyarakat. 2016;32(3):89-94.

8. Sekarwati N, editor Pengaruh Pendidingan Kesehatan terhadap Perilaku anak Sekolah tentang cuci tangan pakai sabun (CTPS) pada siswa di Sekolah Dasar Negeri Kalasan1, Kalasan Sleman Yogyakarta. Jurnal Formil (Forum Ilmiah) KesMas Respati; 2017.

9. Tampara JM, Kairupan B, Boky H. Hubungan pengetahuan, sikap dan tindakan mencuci tangan dengan kejadian diare pada siswa SDN Peta Kabupaten Kepulauan Sangihe. KESMAS. 2017;6(3).

10. Andayani R. Metode drill bermedia Flash Card dalam peningkatan pengetahuan cuci tangan pakai sabun Tunagrahita. Journal of Health Education. 2016;1(1).

11. Kartika M, Widagdo L, Sugihantono A. Faktor-faktor yang berhubungan dengan perilaku cuci tangan pakai sabun pada siswa Sekolah Dasar Negeri Sambiroto 01 Kota Semarang. Jurnal Kesehatan Masyarakat (eJournal). 2016;4(5):339-46.

12. Desiyanto FA, Djannah SN. Efektivitas mencuci tangan menggunakan cairan pembersih tangan antiseptik (hand sanitizer) terhadap jumlah angka kuman. Jurnal Kesehatan Masyarakat (Journal of Public Health). 2013;7(2).

13. Saputri AI, Hasanuddin M, Mery Y. Tren Penyakit Diare Di Kabupaten Buton. Jurnal Kesehatan Masyarakat Celebes. 2019;1(1):33-7.

14. Dinas Kesehatan Kolaka Timur. Profil Kesehatan2018.

15. Mackey A, Gass SM. Second language research: Methodology and design: Routledge; 2015.

16. Sugiyono. Statistik Nonparametris Untuk Penelitian. 2015.

17. Wati N, Yuniar N. Pengaruh Intervensi Penayangan Video terhadap Pengetahuan, Sikap dan Tindakan Tentang Cuci Tangan Pakai Sabun pada Siswa Sdn 10 Kabawo Tahun 2016. (Jurnal Ilmiah Mahasiswa Kesehatan Masyarakat). 2017;2(5).

18. Rachmawati F, Putri HA. Pengaruh Penyuluhan Tentang Cuci Tangan 
Ahmad, N., Tasnim,T., \& Wahab, H.

DOI: 10.36566/ijhsrd/Vol2.Iss1/26

https://ijhsrd.com/index.php/ijhsrd

dengan Media Video terhadap Penerapan Praktik Cuci Tangan di SD

Negeri Nogotirto Yogyakarta:

Universitas' Aisyiyah Yogyakarta; 2016.

19. Zafwan M. Pengaruh Intervensi Promosi Kesehatan Terhadap Pengetahuan Sikap Dan Perilaku Cuci Tangan Pada Anak Kelas V Sekolah Dasar Inpres Borong Jambu I Kota Makassar. Skripsi, Universitas Hasanuddin; 2018.

20. Listyowati D. Pengaruh Intervensi Promosi Kesehatan Terhadap Pengetahuan, Sikap, dan Praktek Cuci Tangan Pakai Sabun pada Siswa Kelas 5 di SDN Pengasinan IV Kota Bekasi Tahun 2012. Depok: Fakultas Kesehatan Masyarakat UI. 2012. 